\title{
Tindak Tutur dalam Instagram Akun@ @ata2bijak dan Kaitannya dengan Bahan Ajar di SMP Kelas VIII
}

\author{
Septina Rahayu' ${ }^{1}$, Denik Wirawati, ${ }^{2}$ \\ Universitas Ahmad Dahlan \\ septina1700003047@webmail.uad.ac.id 1, denik@uad.ac.id²
}

DOI: $\underline{\text { https://doi.org/10.32528/bb.v6i2.5681 }}$

First received: 05-08-2021 Final proof received: 28-10-2021

\begin{abstract}
ABSTRAK
Manusia tidak dapat lepas dari permasalahan hidup. Sehingga memerlukan tuturan yang memotivasi atau bersifat positif, agar menumbuhkan semangat dalam diri seseorang. Ketika menyusun bahasa juga harus menggunakan bahasa yang bersifat mempengaruhi atau memberi saran dengan mengandung makna yang dalam bagi pembacanya. Tujuan dari penelitian ini yaitu untuk mendeskripsikan jenis dan fungsi tindak tutur yang terdapat dalam instagram akun @kata2bijak serta keterkaitan tindak tutur dalam instagram akun @kata2bijak dengan bahan ajar teks poster di SMP kelas VIII. Metode yang digunakan dalam penelitian ini adalah metode analisis padan referensial dengan teknik dasar pilah unsur penentu (PUP) dan teknik lanjutan hubung banding menyamakan (HBS). Data dalam penelitian ini diperoleh dari unggahan instagram akun @kata2bijak. Instagram tersebut mengunggah tuturan kata-kata bijak yang memotivasi atau hal-hal yang sifatnya positif. Hasil dari penelitian ini yaitu ditemukan 1) jenis tindak tutur lokusi yang tuturannya menghasilkan sebuah makna, ilokusi berupa tuturan yang ditunjukkan melalui penekanan komunikatif dan mengharapkan adanya tindakan, dan perlokusi berupa tuturan yang menimbulkan efek bagi pembaca. 2) Fungsi tindak tutur lokusi yaitu representatif kategori menyatakan, fungsi ilokusi dan perlokusi yaitu representatif kategori menyatakan, dan direktif kategori memberi perintah. 3) tindak tutur dalam instagram akun @kata2bijak dapat dikaitkan dengan bahan ajar teks poster di SMP kelas VIII tentang kaidah kebahasaan.
\end{abstract}

Kata kunci: Tindak Tutur; Instagram; Teks Poster

\begin{abstract}
Humans cannot be separated from the problems of life. So it requires speech that motivates or is positive, in order to foster enthusiasm in humans. To compose language, one must also use language that is influencing or giving advice with a deep meaning for the reader. The purpose of this study is to describe the types and functions of speech acts contained in the Instagram account @kata2bijak and the linkage of speech acts in the Instagram account@kata2bijak with poster text
\end{abstract}


teaching materials in class VIII SMP. The method used in this study is the referential equivalent analysis method with the basic determinants of sorting technique (PUP) and the advanced comparison technique (HBS). The data in this study were obtained from uploads to the Instagram account@kata2bijak. Instagram uploads words of wisdom that motivate or things that are positive. The results of this study are: 1) types of locutionary speech acts that produce meaning, illocutionary speech acts that are shown through a communicative emphasis and expect action, and perlocutionary speech acts that have an effect on the reader. 2) The function of speech acts in the locutionary category is representative of stating, illocutionary and perlocutionary functions are representative of the category of stating, and the directive category of giving orders. 3) speech acts in the Instagram account @kata2bijak can be liked with poster text teaching materials in class VIII SMP about linguistic rules

Keywords: Speech Act; Instagram; Poster Text

\section{PENDAHULUAN}

Bahasa adalah alat komunikasi yang digunakan seseorang untuk melakukan interaksi dengan orang lain. Bahasa mempunyai peran penting dalam sebuah kominukasi yang banyak sekali variasinya. Penutur dalam menggunakan bahasa sebagai fungsinya dapat menyampaikan dengan makna yang bermacam-macam. Maka dari itu seorang penutur dalam menyampaikan informasi atau pesan berusaha agar tidak membuat bingung para pembaca dalam memahami kosa kata ataupun maksud dan fungsi dari bahasa yang ingin disampaikan oleh penutur, sehingga dapat tersampaikan dengan jelas. Kumpulan kata-kata yang mudah dipahami dapat memicu pembaca dalam melakukan apa yang dikatakan oleh seorang informan atau motivator.

Bahasa sebagai gejala sosial yang sangat kompleks baik masalah kulturnya, sosialnya, maupun situasionalnya. Kajian pragmatik dipakai untuk menganalisis tindak tutur. Dengan itu dapat diketahui apa fungsi tindak tutur itu diujarkan oleh penuturnya. Karena setiap ujaran yang diucapkan oleh penutur mengandung makna dan maksud tertentu sesuai dengan fungsi masing-masing.

Tindak tutur dalam peristiwa tutur merupakan dua keadaan yang menjadi tanda terjadinya sesuatu yaitu proses komunikasi. Kehidupan manusia tidak bisa lepas dari peristiwa tuturan, karena hal tersebut dapat memberikan informasi kepada lawan tuturnya serta dapat mengerti satu sama lain. Tindak tutur mempunyai banyak macam jenis, salah satu diantarannya dapat dikelompokkan sesuai dengan sifat hubungannya yang meliputi tindak tutur lokusi, ilokusi, dan perlokusi. Tidak hanya pada lisan tuturan manusia juga dapat diekspresikan melalui tulisan.

Chaer \& Leonie (dalam Andini 2017) mengungkapkan bahwa peristiwa tutur berupa gejala sosial dan terdapat hubungan antara penutur dalam situasi dan tempat tertentu, maka tindak tutur lebih cenderung sebagai gejala individual, bersifat psikologis dan ditentukan oleh kemampuan bahasa penutur dalam menghadapi situasi tertentu.

Tindak tutur adalah salah satu kajian pragmatik. Yule (2018) mengatakan bahwa pragmatik merupakan studi yang hubungannya dengan makna yang disampaikan oleh penuturnya atau penulis kemudian pembacanya akan menafsirkan. Pragmatik juga 
memiliki beberapa pengertian yaitu: (a) pragmatik merupakan studi tentang maksud penutur. (b) pragmatik merupakan studi tentang makna kontekstual. (c) pragmatik merupakan studi tentang tentang bagaimana agar lebih banyak disampaikan daripada yang dituturkan. (d) pragmatik merupakan tentang sebuah ungkapan dari jaraknya hubungan. Menurut Rahardi dalam (Yunianto 2017:1-102) pragmatik merupakan cabang ilmu bahasa yang menganilisis maksud dari penutur dengan lingkup konteks situasi lingkungan sosial budaya tertentu.

Leech (dalam Wijana dan Rohmadi, 2011: 5-6) mengatakan bahwa pragmatik yaitu cabang ilmu bahasa yang menganalisis penggunaan bahasa yang digabungkan dengan kaidah bahasa meliputi fonologi, morfologi, sintaksis dan semantik. Dari penjelasan diatas dapat dsimpulkan bahwa pragmatik adalah mempelajari ilmu bahasa berhubungan dengan makna yang penutur sampaikan. Akan tetapi juga dihubungkan dengan situasi atau konteks diluar pemakaian bahasa tersebut. Salah satu bidang pragmatik adalah tindak tutur. Pragmatik dan tindak tutur saling berkaitan karena dapat dilihat pada bidang kajiannya. Tindak tutur dengan pragmatik membahas tentang tuturan yang sesuai dengan konteksnya atau makna. Berdasarkan pendapat beberapa ahli diatas penulis menyimpulkan bahwa pragmatik adalah ilmu yang mempelajari bahasa berkenaan dengan makna yang penutur sampaikan. Akan tetapi juga dihubungkan dengan situasi atau konteks diluar pemakaian bahasa tersebut.

Yule (2018) juga mengatakan bahwa tindak tutur yaitu sebuah tindakan yang disajikan dalam sebuah tuturan. Tuturan yang disajikan memerlukan adanya aspekaspek pragmatik. Aspek-aspek pragmatik yaitu meliputi (1) penutur dan lawan tutur, (2) konteks tuturan, (3) tujuan tuturan, (4) tuturan sebagai tindak verbal.

Yule (2018) membagikan tindak tutur menjadi 3 jenis yaitu (1) lokusi adalah sebuah tuturan bahasa menyatakan sebuah makna., (2) ilokusi merupakan suatu tuturan yang ditunjukkan dengan cara melalui penekanan komunikatif sebuah tuturan. Tindak tutur ilokusi membentuk tuturan dengan beberapa fungsi di dalam pikiran. dan (3) perlokusi yaitu tindak tutur yang menimbulkan akibat atau efek dari sebuah tuturan.

Searle (dalam Yule 2018) mengklasifikasikan lima jenis fungsi umum tindak tutur yaitu: deklarasi, representatif, ekspresif, direktif, dan komisif. Dengan merujuk pada kelima kategori tersebut, Yule (2018) merangkum kelima fungsi umum tindak tutur yaitu sebagai berikut: (1) Deklarasi yaitu tuturan yang menciptakan suatu hal menjadi keadaan yang baru. Tindak tutur ini biasanya berupa memberi izin, mengabulkan, mengangkat, dan mengesahkan. (2) representatif yaitu sebuah tuturan yang diyakini oleh si penutur. Penutur biasanya mengatakan suatu fakta, penegasan, menyimpulkan, mendeskripsikan, melaporkan, dan menuntut. (3) Ekspresif tuturan yang mengatakan sesuatu hal yang dirasakan oleh si penutur. Tuturan ini biasanya menggambarkan pernyataan psikologis seseorang, berupa pernyataan gembira atau berterima kasih atau memberi selamat, kesulitan, kesukaan, kesenangan, kebencian, kesengsaraan, kesedihan dan penyesalan. (4) Direktif adalah tuturan yang digunakan penutur untuk memerintah melakukan sesuatu. meliputi: memberi saran, memohon, memberi perintah, memberi pesan, mengajak, dan bertanya. (5) Komisif tuturan terikat dengan tindakan yang akan 
dilakukan di masa yang akan datang. Tindak tutur ini biasanya meliputi: janji, penolakan, ancaman, ikrar dan penawaran.

Seiring dengan berjalannya waktu yang penuh dengan liku-liku kehidupan pasti banyak yang menghadapi permasalahan hidup. Maka membutuhkan tuturan yang sifatnya memotivasi atau kata-kata positif agar menumbuhkan semangat dalam diri seseorang. Sehingga dalam menyusun bahasa juga harus menggunakan bahasa yang bersifat mempengaruhi atau memberi saran yang lebih khusus dan mengandung makna yang dalam bagi pembacanya.

Tuturan yang mengandung kalimat motivasi atau kata-kata positif sering kali ditemukan dalam media sosial. Zaman sekarang ini kita ketahui bahwa sebagian masyarakat lebih sering menggunakan jejaring sosial untuk berkomunikasi. Salah satu media sosial yang sering digunakan atau dikunjungi oleh masyarakat adalah instagram.

Pernyataan diatas juga diperkuat oleh laporan We Are Social yang menyampaikan jumlah pengguna media sosial instagram di Indonesia pada tahun 2020 mencapai 63 juta jiwa. Dilihat dari banyaknya pengguna instagram dapat membuktikan bahwa aplikasi ini dijadikan sebagai pilihan manusia untuk interaksi sesama pengguna jejaring sosial. Instagram merupakan media sosial yang dimanfaatkan pengguna sebagai alat komunikasi dan untuk menyampaikan informasi. Dengan menggunakan gambar dan kata yang mudah dipahami dalam penyajiannya, informan dapat menyampaikan maksudnya kepada pembaca. Selain fungsinya sebagai tempat saling membagikan foto, vidio, hiburan dan interaksi sosial, instagram juga mempunyai fungsi sebagai tempat menyampaikan ilmu pengetahuan dan sebagai tempat para penulis untuk menyampaikan tutuan-tuturan dan pesannya kepada para pembaca. Instagram sering kali mengunggah kata-kata bijak yang memotivasi para pembaca baik itu dari penulis-penulis lokal, nasional, maupun internasional. Salah satunya yaitu akun instagram @kata2bijak yang mengumpulkan kata-kata bijak dari para penulis atau motivator. Admin mengunggah kata-kata bijak tersebut sesuai dengan kehidupan sosial, yang mempunyai manfaat untuk memotivasi diri seseorang..

Sejalan dengan hal yang dijelaskan diatas maka tuturan dalam unggahan instagram dikaji berdasarkan aspek pragmatik terutama pada tindak tutur. Kajian pragmatik dipakai untuk menganalisis tindak tutur. Dengan demikian dapat diketahui apa jenis dan fungsi tindak tutur itu diujarkan oleh penuturnya. Karena setiap ujaran yang diucapkan oleh penutur mengandung makna dan maksud tertentu sesuai dengan fungsi masing-masing. Kemudian mengaitkan tindak tutur dalam instagram dengan bahan ajar teks poster di SMP kelas VIII mengenai kabahasaan, dengan menggunakan KD 3.4 menelaah pola penyajian dan kebahasaan teks iklan, slogan, atau poster (yang membuat bangga dan memotivasi) dari berbagai sumber yang dibaca dan didengar, dan KD 4.4 menyajikan gagasan, pesan, ajakan dalam bentuk iklan, slogan, atau poster secara lisan dan ditulis.

Penulis menyimpulkan dari penjelasan diatas bahwa penelitian ini dilakukan di instagram akun@kata2bijak terkait dengan jenis dan fungsi tindak tutur sebagai interaksi antara penulis dengan pembacanya. Penelitian ini menggunakan kajian pragmatik sebagai referensi. Penggunaan teori pragmatik sebagai rujukan dalam 
penelitian ini sudah tepat untuk menjawab permasalahan yang ada, karena pragmatik adalah bagian ilmu linguistik yang mempelajari bahasa berdasarkan makna yang disampaikan penutur (penulis) kepada pembaca kemudian ditafsirkan sendiri oleh pembacanya.

\section{METODE PENELITIAN}

Penelitian ini bersifat deskripstif kualitatif. Sudaryanto (2015) mengatakan bahwa deskriptif kualitatif dilakukan dengan cara memaparkan data secara rinci dan tidak mengubah data. Hal ini sejalan dengan tujuan peneliti untuk mendeskripsikan hasil analisis tentang tindak tutur dalam unggahan instagram akun @ kata2bijak tahun 20192020. data yang dijelaskan dalam penilitian ini adalah jenis dan fungsi tindak tutur lokusi, ilokusi, perlokusi. Peneliti juga mendeskripsikan keterkaitan tindak tutur dengan bahan ajar teks poster di SMP kelas VIII.

Metode pengumpulan data yang digunakan dalam penelitian ini adalah metode simak. Metode simak merupakan penyediaan data yang dilakukan dengan menyimak penggunaan bahasa (Sudaryanto, 2015). Teknik pengumpulan data yang digunakan dalam penelitian ini yaitu teknik dasar sadap dan teknik lanjutan dokumentasi dan catat. Teknik dokumentasi digunakan untuk memperoleh data berupa teks kata-kata bijak di instagram. Kemudian teknik catat dilakukan dengan mencatat tindak tutur lokusi, ilokusi dan perlokusi yang terdapat pada unggahan instagram yang dilanjutkan dengan klasifikasi atau pengelompokkan. Data yang diperoleh akan dikumpulkan dan dicatat dalam kartu data.

Metode analisis yang digunakan dalam penelitian ini adalah metode padan. Sudaryanto (2015) mengatakan bahwa metode padan yaitu metode yang alat penutunya berada diluar dari bahasa yang bersangkutan. Metode analisis data yang digunakan dalam penelitian ini yaitu metode padan refrensial karena penentunya adalah kenyataan yang ditunjuk oleh bahasa atau referent bahasa. Teknik yang digunakan yaitu teknik dasar dan teknik lanjutan. Teknik dasar yang digunakan dalam penelitian adalah teknik pilah unsur penentu (PUP), dan teknik lanjutan yaitu teknik hubung banding menyamakan (HBS).

Berikut ini cara yang dilakukan dalam penelitian ini yaitu sebagai berikut; (1) menyimak teks kata-kata bijak pada unggahan instagram dengan teliti. (2) mengidentifikasi data yang termasuk dalam jenis dan fungsi tindak tutur lokusi, ilokusi perlokusi. (3) mencatat hasil identifikasi data tersebut. (4) membuat kesimpulan dan pembahasan mengenai data yang sudah dianalisis dalam penelitian. Data yang telah didapat penulis akan mencatat dalam kartu data agar mempermudah dalam melakukan pencatatan. Kartu data yang digunakan dalam penelitian ini dapat dilihat pada tabel dibawah ini. 
Tabel 1: Kartu Data

\begin{tabular}{|c|c|c|c|}
\hline No & $\begin{array}{c}\text { Nomor } \\
\text { Data }\end{array}$ & Kalimat & Makna \\
\hline 1. & $\mathrm{ttl} / 080819$ & $\begin{array}{lr}\text { "Ketika } & \text { kamu } \\
\text { punya } & \text { tanggung } \\
\text { jawab atas } & \text { sesuatu, } \\
\text { maka bersiaplah } \\
\text { kamu } \\
\text { menerima puji dan } \\
\text { celaannya, } \\
\text { walaupun kamu } \\
\text { tidak menginginkan } \\
\text { hal itu". }\end{array}$ & $\begin{array}{l}\text { Kalimat tersebut adalah jenis } \\
\text { tindak tutur lokusi. Dikatakan } \\
\text { tuturan lokusi karena tidak } \\
\text { bermaksud untuk mempengaruhi. } \\
\text { Hal tersebut dibuktikan dengan } \\
\text { kata untuk, berupa keterangan } \\
\text { tujuan. Makna dari tuturan tersebut } \\
\text { yaitu orang yang mempunyai } \\
\text { tanggung jawab tentang suatu hal } \\
\text { makaharus menerima segala } \\
\text { konsekuensinya. }\end{array}$ \\
\hline
\end{tabular}

\section{Keterangan:}

ttl : jenis tindak tutur lokusi, begitu juga ilokusi (tti)

101219 dan perlokusi (ttp) : tanggal, bulan dan tahun data diunggah

\section{PEMBAHASAN}

\section{Jenis Tindak Tutur dalam Instagram Akun @kata2bijak}

Berdasarkan analisis tindak tutur dalam instagram akun @ kata2bijak dan kaitanya dengan bahan ajar teks poster di SMP kelas VIII, Hasil dari penelitian ini dari 85 tuturan peneliti menemukan jenis tindak tutur lokusi, ilokusi, dan perlokusi. Dari ketiga jenis tindak tutur tersebut yang paling banyak ditemukan dalam tuturan kata-kata bijak pada instagram akun @ kata2bijak adalah tindak tutur ilokusi dengan jumlah data 43 tuturan, kemudian dilanjutkan oleh tindak tutur perlokusi dengan jumlah data 23 dan lokusi yang jumlah datanya 19 tuturan.

\section{a. Tindak Tutur Lokusi}

Tindak tutur lokusi yaitu sebuah tuturan yang kalimatnya menghasilkan sebuah makna. Tindak tutur lokusi biasanya berfungsi untuk menyatakan sesuatu dan tidak bermaksud untuk mempengaruhi. Hal tersebut dapat dilihat dari data dibawah ini.

(1) "Miliki tekad dan komitmen untuk tetap berjuang, berulah kita bisa menapak di puncak kesuksesan.” Andrie Wongso (tt1/240920)

Data (1) merupakan tuturan lokusi karena kalimatnya mengandung makna, kalimatnya hanya untuk menyatakan dan tidak bermaksud untuk mempengaruhi pembaca. Dikatakan tuturan lokusi karena mengandung kalimat pernyataan yang dibuktikan pada kata untuk. Kata untuk menunjukkan keterangan tujuan. Maknanya 
yaitu seseorang yang ingin mencapai sebuah kesuksesan harus memliki tekad dan komitmen dalam berjuang.

(2) "Bangunan kokoh karena pondasinya. Manusia

kokoh karena moralnya."( $\mathrm{tt} 1 / 170120)$

Data (2) merupakan tuturan lokusi karena kalimatnya mengandung makna, kalimatnya hanya untuk menyatakan dan tidak bermaksud untuk mempengaruhi pembaca. Dikatakan tuturan lokusi karena mengandung kalimat pernyataan yang dibuktikan pada kata karena. Kata karena menunjukkan keterangan sebab. Makna yaitu bangunan dapat berdiri kuat karena pondasi begitupun manusia juga menjadi orang yang hebat dan kuat karena moral yang dimiliki.

(3) "Belajar tanpa berpikir itu tidak akan membuahkan apa-apa, tetapi yang berbahaya adalah berpikir tanpa belajar." $\mathrm{ttl} / 290220$

Data (3) merupakan tuturan lokusi karena kalimatnya mengandung makna, kalimatnya hanya untuk menyatakan dan tidak bermaksud untuk mempengaruhi pembaca. Dikatakan tuturan lokusi karena mengandung kalimat pernyataan yang dibuktikan pada kata tetapi. Kata tetapi menunjukkan keterangan perlawanan. Maknanya yaitu jika seseorang belajar tidak memakai pikirannya tidak akan memperoleh hasil apapun tetapi yang membahayakan adalah seseorang yang berpikir tanpa adanya proses belajar.Sehingga berpikir dan belajar merupakan sesuatu yang harus dilakukan bersamaan.

(4) "Dalam hidup ini, apa yang benar-benar kita inginkan tak akan pernah datang dengan mudah. Karena itulah gunanya berjuang." $(\mathrm{ttl} / 120419)$

Data (4) merupakan tuturan lokusi karena kalimatnya mengandung makna, kalimatnya hanya untuk menyatakan dan tidak bermaksud untuk mempengaruhi pembaca. Dikatakan tuturan lokusi karena mengandung kalimat pernyataan yang dibuktikan pada kata dengan . Kata dengan menunjukkan keterangan cara. Makna dari tuturan tersebut yaitu dalam sebuah kehidupan apa yang diinginkan tidak datang dengan cara yang mudah karena sesungguhnya itulah fungsi berjuang.

\section{b. Tindak Tutur Ilokusi}

Tindak tutur ilokusi lebih dominan karena tuturannya bersifat mempengaruhi pembaca dan mengahrapkan adanya tindakan. Hal ini sesuai dengan pengertian tindak tutur ilokusi yang dikatakan oleh Yule (2018) yaitu tuturan yang ditunjukkan dengan cara melalui penekanan komunikatif sebuah tuturan. Tindak tutur ilokusi membentuk tuturan dengan beberapa fungsi di dalam pikiran. mempunyai fungsi untuk menyampaikan sesuatu dengan maksud tertentu dan penutur mengharapkan adanya tindakan yang ingin dicapai pada saat menuturkan sesuatu kepada mitra tutur atau pembacanya. Fungsi komunikatif yang ditemukan pada tuturan instagram akun kata2bijak ini yaitu representatif, dan direktif. Berikut ini data yang diperoleh peneliti. 


\section{1) Representatif}

Representatif yaitu tuturan yang menyatakan sebuah fakta yang diyakini oleh penutur. Tuturan ini biasanya berupa pernyataan, penegasan, kesimpulan dan mendeskripsikan. Tuturan representatif yang ditemukan pada penelitian ini yaitu menyatakan.

(5) "Hiduplah dengan bahagia, karena kita berhak bahagia." ( $\mathrm{tti} / 300820)$

Data (5) dikatakan representatif karena tuturan tersebut menyatakan sebuah fakta yang dipercayai oleh penutur. Penutur mempercayai bahwa setiap orang berhak untuk merasakan bahagia. Kata yang menunjukkan keterangan adalah kata karena, yaitu kata keterangan sebab. Tuturan tersebut mengharapkan adanya tindakan setelah pembaca membaca tuturan tersebut.

(6) “Apa gunanya mata dan hati jika kita menilai seseorang hanya menggunakan telinga." (tti/270319)

Data (6) dikatakan representatif karena tuturan tersebut menyatakan sebuah fakta yang dipercayai oleh penutur. Penutur mempercayai bahwa menilai seseorang tidak hanya menggunakan telinga saja tetapi menggunakan mata dan hati. Kata yang menunjukkan keterangan adalah kata jika yaitu kata keterangan syarat. Tuturan tersebut mengharapkan adanya tindakan setelah pembaca membaca tuturan tersebut.

\section{2) Direktif}

Direktif yaitu tuturan yang memerintah seseorang untuk melakukan sesuatu. Fungsi tindak tutur yang didapatkan pada penelitian ini berupa kalimat perintah. Berikut ini data yang diperoleh peneliti pada tuturan instagram akun@kata2bijak.

(7) "Cobalah selain menjadi orang yang sukses jadilah orang yang bernilai." (tti/190920)

Data (7) dikatakan direktif memberi perintah karena tuturan tersebut memberi perintah pembaca agar menjadi orang sukses dan bernilai. Kata yang menunjukkan memberi perintah yaitu kata cobalah, dikatakan kalimat perintah karena biasanya disertai dengan akhiran -lah. Tuturan tersebut mengharapkan pembaca menjadikan dirinya bernilai setelah membaca tuturan tersebut.

(8) "Jangan meratapi keterbatasan yang kamu miliki, karena sejatinya hal yang besar berawal dari hal yang kecil, yang akrab dengan keterbatasan.” Natta Reza (tti/270319)

Data (8) merupakan direktif memberi perintah karena tuturan tersebut memberi perintah pembaca untuk tidak meratapi keterbatasan diri. Kata yang menunjukkan perintah yaitu kata jangan, yang berarti perintah larangan. Harapan dari tuturan diatas yaitu pembaca menjadi tidak meratapi keterbatasan. 


\section{c. Tindak Tutur Perlokusi}

Tindak tutur perlokusi berupa tuturan yang menimbulkan akibat atau efek bagi pembaca. Tuturan ini mempunyai maksud tertentu untuk mempengaruhi pembacanya sehingga menimbulkan efek bagi pembaca. Efek dan pengaruhnya yang ditimbulkan biasanya dilakukan secara tidak sengaja maupun tidak sengaja. Berikut ini akan dibahas contoh data dalam penelitian ini.

(9) "Hidupalah sesuai kemampuan jangan seperti kemauan". (ttp/090420)

Data (9) merupakan tindak perlokusi karena tuturan tersebut mempunyai maksud untuk mempengaruhi pembaca sehingga ada efek yang ditimbulkan dari tuturan tersebut. Efek dari tuturan tersebut pembaca sadar akan hal itu dan menjadi seseorang yang menjalani kehidupan berdasarkan kemampuan bukan mengikuti keinginan. Hal ini dapat terbukti dari komentar yang sampaikan oleh akun @ftrhrhdh memperlihatkan adanya tindakan yaitu dengan mengatakan ia akan meningkatkan kemampuannya untuk mencapai apa yang diinginkan. Hal tersebut membuktikan adanya efek dari tuturan tersebut. Berikut ini bukti tangkapan layar komentar akun @ftrhrhdh.

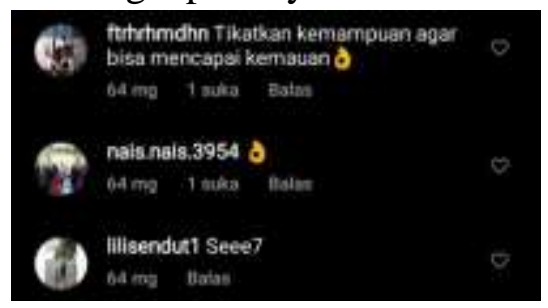

Gambar I: Tangkapan Layar Instagram

(10) "Orang miskin sukses ada. Orang jelek sukses ada. Orang cacat sukses ada, tapi orang males sukses belum ditemukan." (ttp/021020)

Data (10) dikatakan perlokusi, karena tuturan tersebut mempunyai maksud untuk mempengaruhi pembaca sehingga menimbulkan efek bagi pembaca. Kalimat tapi orang males sukses belum ditemukan menunjukkan sindiran sehingga menjadi mempengaruhi seseorang. Efek yang ditimbulkan dari tuturan tersebut yaitu akan mengubah pola pikir orang yang ingin sukses tapi masih bermalas-malasan menjadi bekerja keras untuk mencapai kesuksesan. Hal tersebut dibuktikan dari adanya respon pembaca akun@danielraja2549 melalui kolom komentar yang menyetujui tuturan tersebut dan menunjukkan efeknya yaitu dengan mengajak orang lain untuk melakukan suatu hal. Berikut bukti tangkapan layar komentar pada unggahan tersebut.

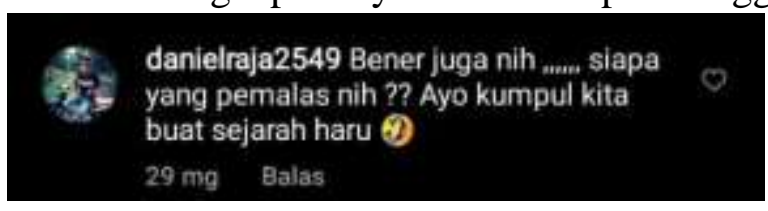

Gambar II: Tangkapan Layar Instagram 
Penelitian relevan juga dilakukan oleh Muhammad Alfiyan dalam skripsinya yang berjudul "Tindak Tutur dalam Teks Pidato Presiden Ir. H. Joko Widodo". Dalam penelitian ini Muhammad menemukan tindak tutur lokusi, ilokusi dan perlokusi dalam teks pidato Presiden Ir. H. Joko Widodo. Peneliti juga menemukan adanya tindak nonverbal berupa tepuk tangan dan tawa para pendengar.

\section{Fungsi Tindak Tutur Lokusi, Ilokusi dan Perlokusi dalam Instagram Akun @ kata2bijak}

\section{a. Tindak Tutur Lokusi}

Fungsi tindak tutur lokusi yang ditemukan dalam tuturan instagram yaitu representatif menyatakan dengan jumlah data 19 tuturan. Berikut data yang akan dibahas.

(11) "Hidup adalah rangkaian pelajaran yang harus dijalani untuk dipahami." (ttl/190319)

Data (11) dikatakan fungsi menyatakan karena tuturan tersebut mengandung kalimat keterangan. Hal tersebut dapat dibuktikan pada kata untuk, yang menunjukkan keterangan tujuan. Tuturan tersebut menyatakan bahwa kehidupan berisi pelajaran dan manusia harus menjalani dan memahaminya.

(12) "Tiada awan di langit yang tetap selamanya. Tiada mungkin akan terus menerus terang cuaca. Sehabis malam gelap gulita lahir pagi membawa keindahan. Kehidupan manusia serupa alam.” RA Kartini $(\mathrm{ttl} / 210419)$

Data (12) dikatakan fungsi menyatakan karena tuturan tersebut mengandung kalimat keterangan. Kata mungkin menunjukkan keterangan kepastian. Tuturan tersebut menyatakan bahwa kehidupan manusia sama dengan alam karena alam juga dapat berubah-rubah misalnya dari

\section{b. Tindak Tutur Ilokusi}

Fungsi tindak tutur yang didapatkan pada unggahan instagram akun @kata2bijak yaitu representatif menyatakan dan direktif memberi perintah. Berikut akan dibahas data yang diperoleh penulis pada unggahan instagram.

\section{1) Representatif}

(13) "Jika kau sudah mencoba, namun gagal, percayalah itu cukup baik sebagian orang bahkan tidak mau mencoba". (tti/010220)

Data (13) merupakan fungsi representatif menyatakan. Tuturan yang menunjukkan pernyataan terdapat pada kata jika, yaitu keterangan syarat. tuturan tersebut menyatakan bahwa saat seseorang mencoba tapi gagal, apa yang sudah kamu lakukan itu sudah cukup baik karena tidak semua orang mau mencoba.

(14) "Kesalahan terburuk adalah ketika kamu tidak percaya 
dengan kemampuan dirimu sendiri. Jangan menyerah!.” (tti/091120)

Data (14) merupakan fungsi representatif menyatakan. Dikatakan menyatakan karena kalimat mengandung keterangan. Kata dengan pada kalimat tersebut menunjukkan keterangan cara. Tuturan tersebut menyatakan bahwa tidak mempercayai kemampuan diri sendiri merupakan sebuah kesalahan yang paling buruk.

2) Direktif

(15) "Carilah tempat dimana dirimu dihargai bukan dibutuhkan, sebab banyak yang datang karena butuh, tapi lupa bagaimana cara menghargai." (tti/050319)

Data (15) merupakan fungsi direktif memberi perintah. Dikatakan direktif memberi perintah karena kalimatnya mengandung kalimat perintah. Kata yang menunjukkan kalimat perintah yaitu pada kata carilah, yang diikuti akhiran -lah. Tuturan tersebut memperintahkan pembaca untuk mencari tempat dimana kamu akan dihargai bukan dibutuhkan.

(16) "Jangan pernah berhenti pada satu titik, teruslah melangkah untuk menambah wawasan.” (tti/270720)

Data (16) merupakan fungsi direktif memberi perintah. Dikatakan tuturan memberi perintah karen tuturan tersebut mengandung kalimat perintah. Kata yang menunjukkan kalimat perintah terdapat pada kata Jangan, yang berupa perintah larangan. Tuturan diatas memberi perintah untuk tidak berhenti dalam satu titik dan terus melangkah agar wawasan semakin bertambah.

\section{c. Tindak Tutur Perlokusi}

Fungsi tindak perlokusi yang diperoleh pada penelitian ini yaitu fungsi representatif menyatakan dan direktif memberi perintah berikut akan dibahas data yang diperoleh dari tuturan instagram akun @kata2bijak.

1) Representatif

(17) "Kegagalan terbesar dalam kehidupan ini bukan karena jatuh tapi karena tidak pernah berani berlari." (ttp/091219)

Data (17) merupakan fungsi representatif menyatakan. Dikatakan representatif menyatakan karena tuturan tersebut mengandung kalimat keterangan. Kata karena pada kalimat tersebut menunjukkan keterangan sebab. Tuturan diatas menyatakan bahwa seseorang dikatakan gagal bukan karena jatuh tapi karena ia tidak pernah berani mencoba.

(18) "Tidak ada kesuksesan instant dalam hidup ini, bahkan untuk membuat mie instant sekalipun kita harus merebus air terlebih dahulu." (ttp/120319) 
Data (18) merupakan fungsi representatif. Dikatakan representatif karena tuturan tersebut menyatakan kepada pembaca yang ditunjukkan melalui kata keterangan. Kata untuk dalam kalimat diatas menununjukkan keterangan tujuan. Tuturan diatas menyatakan bahwa tidak ada kesuksesan yang instan didalam sebuah kehidupan sehingga semuanya butuh proses.

\section{2) Direktif}

(19) "Hidup ini singkat, tersenyumlah mumpung kamu masih memiliki gigi.” (ttp/060419)

Data (19) merupakan fungsi direktif memberi perintah. Dikatakan direktif memberi perintah karena tuturan tersebut mengandung kalimat perintah. Kata yang menunjukkan kalimat perintah yaitu pada kata tersenyumlah, yaitu kata tersebut diikuti akhiran -lah. Tuturan diatas memperintahkan kepada pembaca untuk selalu bahagia dengan menunjukkan senyuman diwajah selagi masih muda.

(20) "Jangan pernah merendahkan diri sendiri. Kamu bukan seperti apa yang orang lain bilang. Kamu adalah kamu." (ttp/230419)

Data (20) merupakan fungsi direktif memberi perintah. Dikatakan direktif memberi perintah karena tuturan tersebut mengandung kalimat perintah. Kata yang menunjukkan memberi perintah terdapat pada kata jangan, berupa perintah larangan. Tuturan tersebut memberi perintah kepada pembaca untuk tidak merendahkakn dirinya

Fungsi tindak tutur dalam unggahan instagram akun kata2bjak yang paling sering ditemukan pada penelitian ini berupa fungsi representatif menyatakan dengan jumlah data 45 tuturan, fungsi direktif memberi perintah yang berjumlah 35 tuturan. Fungsi ekspresif, komisif dan deklarasi tidak dapat ditemukan dalam penelitian ini, fungsi representatif lebih dominan ditemukan dalam penelitian ini karena pada tuturan katakata bijak bersifat menyatakan dan memberi perintah kepada pembaca.

Hal ini sejalan dengan pendapat Yule (2018) yang mengatakan bahwa representatif yaitu tindak tutur yang mengemukakan apa yang diyakini oleh si penutur. Penutur biasanya mengatakan suatu fakta, penegasan, menyimpulkan, mendeskripsikan, melaporkan, dan menuntut. Direktif berupa tutuan yang digunakan untuk memerintah seseorang agar pembaca atau mitra tutur melakukan sesuatu. Tindak tutur ini biasanya meliputi: memberi saran, memohon, memberi perintah, memberi pesan, mengajak, dan bertanya.

Hal tersebut sesuai juga dengan Penelitian sejenis yang dilakukan oleh Amanah dan Wahyu dalam jurnalnya yang berjudul "Tuturan Ilokusi Bahasa Motivasi Mario Teguh pada Jejaring Sosial Facebook" pada penelitian ini penulis menyimpulkan bahwa fungsi yang lebih dominan yaitu asertif berupa tuturan pernyataan, dan tuturan lain juga banyak digunakan yaitu tuturan ilokusi direktif yang berupa nasehat. 


\section{Keterkaitan Tindak Tutur dalam Instagram Akun@kata2bijak dengan Bahan Ajar Teks Poster di SMP Kelas VIII}

Menurut Hamalik dalam (Nirwanti 2017) mengatakan bahwa pembelajaran merupakan sebuah kombinasi yang penyusunannya berdasarkan unsur-unsur. Bahasa selalu digunakan dalam proses penyampaian informasi keilmuan dalam sebuah pembelajaran. Oleh karena itu bahasa menjadi penyebab terpenting dalam proses pembelajaran yang memerlukan perhatian. Proses pembelajaran bahasa indonesia terdiri dari empat aspek yang menjadi ruang lingkup dalam pembelajaran bahasa yaitu: keterampilan berbahasa, keterampilan membaca, keterampilan menyimak, dan keterampilan berbicara. Dalam proses pembelajaran memerlukannya bahan ajar sebagai alat yang digunakan dalam perangkat pembelajaran.

Pembelajaran Bahasa memiliki peran yang penting dalam kehidupan masyarakat, melalui penggunaan bahasa kita dapat melakukan interaksi, saling berbagi ide, gagasan dan menyampaikan pendapat. Satu diantara banyak mata pelajaran, bahasa indonesia wajib untuk dipelajari oleh siswa. Materi pembelajaran yang dipelajari dalam mata pelajaran ini misalnya kebahasaan, kemampuan berbahasa dan kesastraan. Salah satu diantara materi yang menjadi bahan pembelajaran bahasa indonesia yaitu pola pengembangan kalimat dan keterampilan berbahasa.

Pembelajaran tentang kebahasaan tersebut sesuai dengan KD 3.4 menelaah pola penyajian dan kebahasaan teks iklan, slogan, atau poster (yang membuat bangga dan memotivasi) dari berbagai sumber yang dibaca dan didengar, dan KD 4.4 menyajikan gagasan, pesan, ajakan dalam bentuk iklan, slogan, atau poster secara lisan dan tulis. Sejalan dengan hasil penelitian ini, pembelajaran kebahasaan teks poster kelas VIII SMP terdapat pada indikator pencapaian kompetensi (IPK) 3.4.1 menelaah pola penyajian dan ciri kebahasaan teks poster dan 4.4.1 menyusun teks poster berdasarkan pola penyajian dan teks kebahasaan yang benar.

Penelitian ini mempunyai judul "Tindak Tutur dalam Instagram Akun @kata2bijak dan Kaitannya dengan Bahan Ajar Teks Poster di SMP kelas VIII” yang akan dikaitkan dengan bahan ajar materi teks poster. Hasil dari penelitian ini yaitu bahan ajar yang akan dimanfaatkan sebagai proses pembelajaran bahasa indonesia kelas VIII SMP khususnya materi teks poster. Isi materi dalam bahan ajar pembelajaran ini yaitu, 1) pola penyajian, 2) ciri kebahasaan, dan (3) cara menyusun teks poster.

Menurut National Centre For Competency Based Learning (Prastowo, 2011:16) bahan ajar yaitu semua jenis media yang dimanfaatkan seorang guru dalam membantu proses terlaksananya pembelajaran. Jenis-jenis bahan ajar dapat terbagi kedalam dua jenis yaitu berdasarkan bentuknya dan berdasarkan cara kerja. Berdasarkan bentuk bahan ajar terbagi kedalam empat bagian, meliputi: 1) dalam bentuk cetak, 2) audio, 3) bahan ajar audiovisual, dan 4) interaktif. Berdasarkan cara kerjanya dibedakan menjadi lima macam yaitu 1) bahan ajar yang tidak diproyeksikan, 2) bahan ajar yang diproyeksikan, 3) dalam bentuk audio, 4) ditampilkan berupa vidio, dan 5) bahan ajar (media) komputer. 
Hamdani (20011: 219) berpendapat bahwa bahan ajar merupakan sebuah informasi, alat atau teks yang digunakan oleh seorang pengajar untuk kegiatan belajar dan proses pelaksanaan evaluasi. Menurut Wahono dalam (Subakti 2018: 85-97) mengatakan bahwa poster adalah berupa selebaran yang sering ditemukan di tempat umum. Pembuatan poster dilakukan dengan desain menarik yang memanfaatkan gambar, tulisan dan menggunakan bahasa yang unik, indah serta variasi kalimat yang tepat.

Keterkaitan tindak tutur dengan bahan ajar teks poster dari penelitian ini yaitu terdapat pada rumusan (2) berupa fungsi tindak tutur yang dikaitkan dengan KD 3.4 tentang kaidah kebahasaan teks poster. Kaidah kebahasaan teks poster yaitu meliputi: (1) menggunakan kalimat yang bersifat persuasif atau mempengaruhi. (2) menggunakan kalimat imperatif atau mengajak. (3) kata-katanya singkat dan mudah dipahami. (4) kata-katanya cenderung memberikan perintah, berisi hal-hal yang positif dan dapat memotivasi atau memberi pesan pembaca.

Sejalan dengan ciri kebahasaan teks poster fungsi tindak tutur lokusi, ilokusi dan perlokusi merupakan tuturan yang menyatakan pendapat, memberi perintah, dan berisi tentang hal-hal poistif yang bersifat mempengaruhi. Dari hasil penelitian yang telah dilakukan, tindak tutur kata-kata bijak dalam unggahan instagram peneliti menyimpulkan bahwa penelitian ini dapat dikaitkan dengan pembelajaran bahasa indonesia teks poster di SMP kelas VIII, Hasil dari penelitian ini yaitu bahan ajar pembelajaran teks poster. Isi bahan ajar yaitu tetang kebahasaan dan pola penyajian teks poster di SMP kelas VIII.

Penelitian serupa juga dilakukan oleh Evana (2020) dalam skripsinya yang berjudul "Tindak Tutur Imperatif dalam Caption Akun Teladan Rasul di Media Sosial Instagram dan Implikasinya Terhadap Pembelajaran Bahasa Indonesia di SMA". hasil dari penelitian yang dilakukan yaitu tuturan imperatif banyak sekali ditemukan kemudian hasil penelitian dapat dikaitkan dengan pembelajaran bahasa indonesia di SMA.

\section{SIMPULAN}

Berdasarkan pada pemabahasan diatas peneliti menyimpulkan sebagai berikut: (1) jenis tindak tutur yang ditemukan pada penelitian ini yaitu lokusi berupa tuturan yang menghasilkan sebuah makna dan menyatakan kepada pembaca, ilokusi berupa tuturan yang ditunjukkan melalui penekanan komunikatif dan mengharapkan adanya tindakan dari pembaca, dan perlokusi berupa tuturan yang menimbulkan efek bagi pembacanya. (2) fungsi tindak tutur lokusi, ilokusi dan perlokusi yaitu tuturan representatif menyatakan, dan ilokusi dan perlokusi direktif memberi perintah. (3) tindak tutur dalam instagram akun @kata2bijak dapat dikaitkan dengan bahan ajar teks poster yang akan dimanfaatkan sebagai bahan ajar untuk proses pembelajaran yaitu terkait dengan KD 3.4 menelaah pola penyajian dan kebahasaan teks iklan, slogan, atau poster (yang membuat bangga dan memotivasi) dari berbagai sumber yang dibaca dan didengar, dan KD 4.4 menyajikan gagasan, pesan, ajakan dalam bentuk iklan, slogan, atau poster secara lisan dan tulis. 
Berdasarkan hasil analisis data yang telah dilakukan terdapat beberapa saran yang ingin disampaikan yaitu: (1) Bagi peneliti lain, hasil penelitian ini diharapkan dapat menambahkan referensi untuk kajian pragmatik kehusunya pada tindak tutur. Diharapkan penelitian ini dapat menimbulkan adanya ide-ide baru dari peneliti lain yang terkait dengan tindak tutur. (2) Bagi pendidik diharapkan dapat menambah wawasan dan memanfaatkan penelitian ini sebagai bahan ajar teks poster SMP kelas VIII. (3) Bagi peserta didik atau pembaca diharapkan mampu mempelajari jenis tindak tutur lokusi, ilokusi, dan perlokusi pada poster untuk meningkatkan keterampilan dalam menafsirkan pola penyajian dan ciri kebahasaan teks poster.

\section{REFERENSI}

Ainun, D.T.F. (Juni 25). Pengertian poster: fungsi, ciri-ciri, jenis, tujuan, \& contoh poster. diperoleh dari. Diakses dari https://salamadian.com/pengertian-poster/

Alfiyan, M. (2016). Tindak Tutur dalam Teks Pidato Presiden Ir. H Joko Widodo.(Universitas Mataram). Mataram.

Hamdani. (2011). Strategi belajar mengajar. Bandung: Pustaka Setia.

Hijriah, A., Damayanti, W. (2016). Tuturan Ilkusi Bahasa Motivasi Mario Teguh Pada Jejaring Sosial Facebook. Balai Bahasa Kalimantan Barat. Balai Bahasa Kalimantan Barat. 8 (Edisi September 2016), 1-12.

KBBI. (2021)Kamus Besar Bahasa Indonesia (KBBI). [Online].

Nirwanti, Y. (2017). Analisis Tindak Tutur Representatif dan Direktif pada Iklan Layanan Masyarakat pada Radio Fortuna FM Kotoarjo Periode Tahun 20122016 dan Skenario Pembelajarannya di kelas XII SMA. Universitas Muhammadiyah Purworejo.

Permatasari, I.D. (2019). Tindak Tutur Ilokusi Ujaran Kebencian Facebook Tahun 2017-2019. (Universitas Negeri Semarang). Diakses dari http://lib.unnes.ac.id/id/eprint/35622

Sanyya, E. (2020). Tindak Tutur Imperatif dalam Caption Akun Teladan Rasul di Media Sosial Instagram dan Implikasinya Terhadap Pembelajaran Bahasa Indonesia di SMA. Universitas Pancasakti Tegal. Diakses dari http://repository.upstegal.ac.id/id/eprint/1691

Subakti, H. (2018). Pengembangan Bahan Ajar Menulis Slogan dan Poster dengan Pendekatan Proses Siswa Kelas VIII SMP Syaicona Cholil Samarinda. Jurnal Pendas Mahakam, 3(2), 85-97.

Sudaryanto. (2015). Metode dan Aneka Teknik Analisis Linguistik. Yogyakarta: Sanata Dharma University Press.

Wijana, I. P. D., \& Rohmadi, M. (2011). Analisis Pragmatik, Kajian Teori dan Analisis. Surakarta: Yuma Pustaka. 
Yule, G. (2018). Pragmatik (edisi terjemahan Indah Fajar Wahyuni). Yogyakarta: Pustaka Pelajar.

Yunianto, A. D. (2017). Bentuk Tindak Tutur Ilokusi Dalam Program Sentilan Sentilun. (Universitas Sanata diakses dari http://repository.usd.ac.id/id/eprint/12464 